\begin{tabular}{|c|l|}
\hline Title & The coral $\delta 15 \mathrm{~N}$ record of terrestrial nitrate loading varies with river catchment land use \\
\hline Author(s) & Yamazaki, A.; Watanabe, T.; T sunogai, U.; Hasegawa, H.; Y amano, H. \\
\hline Citation & $\begin{array}{l}\text { Coral Reefs, 34, 353-362 } \\
\text { https://doi.org/10.1007/300338-014-1235-1 }\end{array}$ \\
\hline Issue Date & 201410-28 \\
\hline Doc URL & http://hdl.handle.net/2115/60729 \\
\hline Rights & The final publication is available at Springer. \\
\hline Type & article (author version) \\
\hline File Information & Coral Reefs_2014.pdf \\
\hline
\end{tabular}

Instructions for use 


\section{The coral $\delta^{15} \mathrm{~N}$ record of terrestrial nitrate 2 loading varies with river catchment land use

4 A. Yamazaki1\&2, T. Watanabe ${ }^{1}$, U. Tsunogai ${ }^{3}$, H. Hasegawa ${ }^{4}$, H. 5 Yamano $^{5}$

1. Graduate School of Science, Hokkaido University, N10W8, Kita-ku, 8 Sapporo, 060-0810, Japan

9 2. Atmosphere and Ocean Research Institute, University of Tokyo, 10 5-1-5, Kashiwanoha, Kashiwa, Chiba, 277-0882, Japan.

11 3. Graduate School of Environmental Studies, Nagoya University, 12 Furo-cho, Chikusa-ku, Nagoya, 464-8601, Japan

13 4. Department of Geography and Environmental Studies, Kokushikan 14 University, 4-28-2, Setagaya, Setagaya-ku, Tokyo, 154-8515, Japan

15 5. Center for Environmental Biology and Ecosystem Studies, National 16 Institute for Environmental Studies, 16-2, Onogawa, Tsukuba, Ibaraki,

Correspondence to: A. Yamazaki (zaki@aori.u-tokyo.ac.jp)

\section{Abstract}

We analysed the nitrogen isotopes in two coral cores $\left(\delta^{15} \mathrm{~N}_{\text {coral }}\right)$ from the mouth of the Todoroki River, Ishigaki Island, Japan to examine whether the $\delta^{15} \mathrm{~N}_{\text {coral }}$ reflects the runoff of nitrate related to the land use in the river catchment. The two coral cores were used to examine the seasonal variation in $\delta{ }^{15} \mathrm{~N}_{\text {coral }}$ for 14 years (CORE1; 1993-2007) and the annual variation of $\delta^{15} \mathrm{~N}_{\text {coral }}$ for 52 years (CORE2; 1958-2010). $\delta^{15} \mathrm{~N}_{\text {coral }}$ In CORE1, the 5 -month running mean of $\delta^{15} \mathrm{~N}_{\text {coral }}$ was positively correlated with that of monthly precipitation, excluding all strong precipitation events $(>150 \mathrm{~mm}$ day-1). In CORE2, the $\delta{ }^{15} \mathrm{~N}_{\text {coral }}$ mean in the earlier period (1958-1980) was $1.0 \%$ greater than that in the later period (1981-2010). The annual averages of $\delta^{15} \mathrm{~N}_{\text {coral }}$ are positively correlated with the total precipitation in the rainy season (May-June) for both time periods. The difference in the $\delta^{15} \mathrm{~N}_{\text {coral }}$ between the earlier and later periods would be caused by the land use changed from paddy fields with ${ }^{15} \mathrm{~N}$-rich manure to sugar cane fields in the early 1980s. Although some uncertainties still remain regarding the precision of $\delta^{15} \mathrm{~N}$ coral proxy records, this study emphasises the clear potential for their use in reconstructing terrestrial nitrate discharge records from corals.

Keywords: coral skeletons, nitrogen isotopes, nitrate, land-use, river 


\section{Introduction}

43 Coral reef degradation is rapidly increasing throughout the world due to local and

44 global stresses such as pollution and climate change (Bellwood et al. 2004;

45 Hoegh-Guldberg et al. 2007; De'ath et al. 2012). With anthropogenic

46 development of the areas surrounding coastal reefs, terrestrial runoff into the coral

47 reefs is impacting reef water quality and ecosystem functioning (Fabricius 2005).

48 The detection of nutrient sources is useful to assess reef environments. The

49 nitrogen isotope compositions of seawater, macroalgae, sediments and coral tissue

50 have been used to trace the sources of nitrogen in coral reefs (e.g., Heikoop et al.

51 2000; Miyajima et al. 2001; Umezawa et al. 2002a, 2008; Yamamuro et al. 2003).

52 Coral skeletons have been widely used as palaeo-environmental archives in coral

53 reefs and communities (e.g., reviewed by Druffel et al. 1997; Gagan et al. 2000;

54 Grottoli and Eakin 2007). Marion et al. (2005) suggested that the nitrogen isotopic

55 signature in the organic matrix of coral skeletons $\left(\delta^{15} \mathrm{~N}_{\text {coral }}\right)$ records the history of 56 nutrient loading into coral reefs. High-resolution analysis of $\delta^{15} \mathrm{~N}_{\text {coral }}$ has also 57 suggested that $\delta^{15} \mathrm{~N}_{\text {coral }}$ records the origins of nitrogen in coral reefs at the seasonal 58 scale (Uchida et al. 2008; Yamazaki et al. 2011a). $\delta^{15} \mathrm{~N}_{\text {coral }}$ could be a useful proxy

59 to reconstruct nitrogen loading into coral reefs.

61 The Todoroki River flows into the Shiraho coral reef at the southeast end of 62 Ishigaki Island, and is one of the major nitrate sources for the sites in this study 63 (Blanco et al. 2010). Seasonal variation in the nitrogen isotopic signature of 64 nitrate $\left(\delta^{15} \mathrm{~N}_{\text {nitrate }}\right)$ at the mouth of the Todoroki River suggests that the nitrate 65 inflow from the Todoroki River is triggered by the rainy season and typhoons 66 (Electronic Supplemental Material, ESM Fig. S1). Another form of dissolved 67 inorganic nitrogen, ammonium, is primarily emitted from reef sediments and sea 68 grass beds, not from the Todoroki River (Miyajima et al. 2001; Blanco et al. 69 2008).

71 Yamazaki et al. (2011b) observed a correspondence among the intra reef

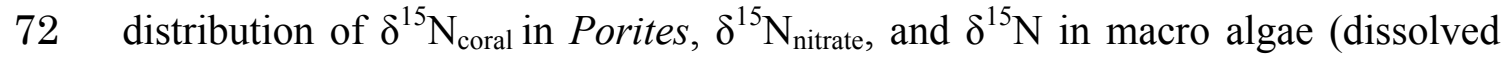
73 inorganic nitrogen (DIN) consumers, reported by Umezawa et al. 2002a).

74 These results suggested that $\delta^{15} \mathrm{~N}_{\text {coral }}$ in the Shiraho coral reef records the variation

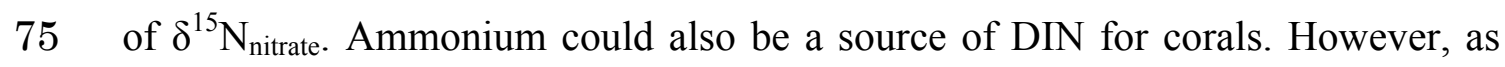


76 nitrogen sources, the volume of nitrate at the mouth of the Todoroki River is

77 much larger than that of ammonium. The concentrations of ammonium are less

78 than $1 \%$ of those of nitrate in this study site (Blanco et al. 2008).

80 In this study, we examined $\delta^{15} \mathrm{~N}_{\text {coral }}$ as a proxy to reconstruct nitrate loading from

81 terrestrial origins into Shiraho coral reef, Ishigaki Island, Japan. Yamazaki et al.

82 (2011b) reported that a zonal distribution of $\delta^{15} \mathrm{~N}_{\text {coral }}$ was found within the Shiraho

83 coral reef, which corresponded with the $\delta^{15} \mathrm{~N}$ of seawater nitrate. The distribution

84 of $\delta^{15} \mathrm{~N}_{\text {nitrate }}$ was from two nitrate sources: the Todoroki River flowing into the

85 reef and slight nitrate $(<1 \mu \mathrm{M})$ in water from the outer reef ocean.

87 We collected coral cores at the mouth of Todoroki River to reconstruct the origins

88 of nitrate loading into coral reefs. We (1) investigated the relationship between the

89 seasonal variation of $\delta^{15} \mathrm{~N}_{\text {coral }}$ and precipitation, and (2) compared the 52-year

90 record of the annual $\delta^{15} \mathrm{~N}_{\text {coral }}$ to changes in the land-use history in the Todoroki

91 River catchment.

$93 \quad$ Materials and Methods

94 Study site

95 Coral cores were collected at the mouth of the Todoroki River on Ishigaki Island, 96 southwest of the Ryukyu Islands, Japan $\left(24^{\circ} 21^{\prime}-31^{\prime} \mathrm{N}, 124^{\circ} 4^{\prime}-16^{\prime} \mathrm{E}\right)$; this site has 97 a subtropical climate. The river catchment area is composed of sugarcane, pasture, 98 pineapple and paddy fields (Fig. 1a). The mouth of Todoroki River crosses the 99 coral reef (Fig. 2a). The average annual precipitation is approximately $2000 \mathrm{~mm}$, $10060 \%$ of which falls in the rainy season from May to June or is caused by a 101 typhoon in August or September.

103 To analyse the $\delta^{15} \mathrm{~N}_{\text {nitrate }}$ and the oxygen isotopic signature of nitrate $\left(\delta^{18} \mathrm{O}_{\text {nitrate }}\right.$ ), 104 we collected water samples in March and August 2009 from the Todoroki River 105 (RW1-3), ground water in sugar cane (GW1 and GW2), paddy fields (GW3), and 106 a cattle barn (GW4) from the drainage basin (Fig. 1a). We also collected rainwater 107 samples in August 2009. 
110 Based on the data in Table 1 of Yamazaki et al. (2011b), we compared the nitrate

111 concentrations and $\delta^{15} \mathrm{~N}_{\text {nitrate }}$ of seawater samples collected at $50 \mathrm{~m}$ intervals along

112 a sampling line from the mouth of the Todoroki River to offshore (Fig. 2b).

$113 \delta^{15} \mathrm{~N}_{\text {nitrate }}$ was positively correlated $(\mathrm{R}=0.85, \mathrm{P}<0.004)$ with the logarithm of

114 nitrate concentrations in the range from $+2 \%$ in the outer ocean nitrate to $+9 \%$ in

115 the nitrate from the Todoroki River. Time series analyses of $\delta^{15} \mathrm{~N}_{\text {coral }}$ at the mouth

116 of the Todoroki River demonstrated the $\delta^{15} \mathrm{~N}_{\text {nitrate }}$ changes with terrestrial nitrate

117 discharges.

119 Coral core sampling

120 Coral drilling was performed at the mouth of Todoroki River using an air drill 121 (Adachi and Abe 2003). On 2 September 2007, we vertically drilled a 60-cm 122 length core from the top of a live Porites coral colony at $272 \mathrm{~m}$ offshore from the 123 shoreline (CORE1; project ID: SPc070902, sampled from N24²3'12.40", 124 E1241' $20.56^{\prime \prime}, \sim 2 \mathrm{~m}$ depth). The record distance of CORE1 was 14 years 125 (1993-2007), which was determined in monthly resolution by an age model using 126 carbonate $\mathrm{Sr} / \mathrm{Ca}$ ratios and oxygen isotopes (K. Ohmori, pers. comm.). The annual 127 growth rate of CORE1 was approximately $20 \mathrm{~mm} \mathrm{year}^{-1}$ (ESM Fig.S2). 128 Microsampling was performed at 3-mm ( 2 month) intervals along the major 129 growth axis to obtain $30-40 \mathrm{mg}$ of coral powder $(\sim 100 \mu \mathrm{molN})$. We reconstructed 130 the seasonal variation in the $\delta^{15} \mathrm{~N}_{\text {coral }}$ in CORE1 for the past 14 years. To sample a 131 longer core, we also performed coral micro-atoll boring on 2 September 2010 132 (CORE2; project ID: IStr-p100902-2, sampled from N24²3'04.6", 133 E124 $\left.15^{\prime} 21.5^{\prime \prime}\right), 299 \mathrm{~m}$ offshore from the shoreline. CORE2, which was $1.2 \mathrm{in}$ 134 length, was horizontally drilled from the side of a micro-atoll with a depth of less 135 than $2 \mathrm{~m}$. The age model of CORE2 was also determined by fitting the density 136 bands of $\mathrm{X}$-radiographs and $\mathrm{Sr} / \mathrm{Ca}$ ratios and oxygen isotopes (T. Miyaji, personal 137 communication), and its record distance was the sub-annual variation in $\delta^{15} \mathrm{~N}_{\text {coral }}$. 138 The age models and X-radiographs of the two cores (CORE1 and CORE2) were 139 described in Inoue et al. (2014) and ESM Figure S2.

\section{$141 \quad \boldsymbol{\delta}^{15} \mathbf{N}_{\text {coral }}$ analysis}

142 The sampled powder was treated with $\mathrm{NaOH}\left(2 \mathrm{~N}, 60^{\circ} \mathrm{C}\right)$ for $3 \mathrm{~h}$ and rinsed using 143 Milli-Q water to remove the extra organic matter (e.g., algal and fungal 144 bioeroders) in the coral powder according to Yamazaki et al. (2013), who 
145 suggested that this cleaning process provides the same values of $\delta^{15} \mathrm{~N}$ in

146 intra-crystal aragonite as determined by stepwise heating methods. The tissue

147 layer in the core top ( $<4 \mathrm{~mm}$ depth from the top of the core) was not used for 148 nitrogen isotope analysis.

150 Nitrogen isotope values of organic nitrogen in coral skeletons were analysed using 151 the method developed by Tsunogai et al. (2008) and Yamazaki et al. (2011b). This 152 method involves oxidation/reduction methods such as the oxidation of organic 153 nitrogen to nitrate using persulphate (Knapp et al. 2005; Tsunogai et al. 2008), 154 reduction of nitrate to nitrite using spongy cadmium, and further reduction of 155 nitrite to nitrous oxide using sodium azide. Wet conditions were maintained 156 throughout the chemical treatments to avoid the evaporation of dissolved organic 157 nitrogen, which would affect the $\delta^{15} \mathrm{~N}$ values obtained after the re-drying process 158 after acid treatment and to recover $\delta^{15} \mathrm{~N}$ in coral skeletons without isotope 159 fractionation.

161 First, organic nitrogen in the coral skeletons was oxidised to $\mathrm{NO}_{3}^{-}$using 162 persulphate under alkaline conditions. The coral skeletal powder $(28 \mathrm{mg})$ was 163 decalcified with $0.6 \mathrm{ml}$ of $1 \mathrm{~N} \mathrm{HCl}$ in $30-\mathrm{ml}$ Teflon bottles for $2 \mathrm{~h}$. Then, $0.4 \mathrm{ml}$ of 164 deionised water (DIW) and $50 \mu \mathrm{l}$ of oxidising reagent (peroxodisulphate; 165 Tsunogai et al. 2008) were added. The Teflon bottles were capped tightly with 166 Teflon screw caps and autoclaved for $1 \mathrm{~h}$ at $121^{\circ} \mathrm{C}$. After the samples were cooled 167 for 8 hours, needle crystals of $\mathrm{CaSO}_{4}$ were deposited. A 1-ml volume of the 168 sample solution, excluding the $\mathrm{CaSO}_{4}$ crystals, and $9 \mathrm{ml}$ of DIW were pipetted 169 into 10-ml vials with butyl rubber caps. For two coral samples, we prepared 170 internal standards, including L-alanine $\left(\delta^{15} \mathrm{~N}=+1.78 \pm 0.06 \% \mathrm{AIR}\right)$, L-histidine $171\left(\delta^{15} \mathrm{~N}=-7.96 \pm 0.05 \% \mathrm{AIR}\right)$, and tuna flakes $\left(\delta^{15} \mathrm{~N}=+12.55 \pm 0.06 \% \mathrm{AIR}\right)$. Organic 172 nitrogen standards diluted with DIW $(400 \mu \mathrm{M}-\mathrm{N})$ were oxidised to $\mathrm{NO}_{3}{ }^{-}$using the 173 same methods. The internal standard samples contained the organic material of 174 the coral skeletons $(1 \mathrm{ml}), 400 \mu \mathrm{M}-\mathrm{N}(1 \mathrm{ml})$, and $8 \mathrm{ml}$ of DIW in 10-ml vials. $175 \mathrm{Next}, \mathrm{NO}_{3}^{-}$was reduced to $\mathrm{NO}_{2}^{-}$by adding $0.5 \mathrm{~g}$ of spongy cadmium to each vial, 176 followed by $0.3 \mathrm{~g}$ of $\mathrm{NaCl}$ and $0.1 \mathrm{ml}$ of a $1 \mathrm{M} \mathrm{NaHCO}_{3}$ solution to yield a final $177 \mathrm{pH}$ of approximately 8.5. The samples were then shaken for $5 \mathrm{~h}$ on a horizontal 178 shaker at a rate of 2 cycles $\sec ^{-1}$ Subsequently, $\mathrm{NO}_{2}^{-}$was reduced to $\mathrm{N}_{2} \mathrm{O}$ using 
179 sodium azide. Then, $10 \mathrm{ml}$ of the samples was decanted into a clean 20-ml vial 180 and capped tightly with a butyl rubber cap. After purging with helium to evacuate 181 the air from the headspace and the sample solution for $2 \mathrm{~min}, 0.4 \mathrm{ml}$ of 182 azide/acetic acid buffer was added to each vial via a syringe, and the mixture was 183 shaken. After $2 \mathrm{~h}$, the solution was made basic by adding $0.2 \mathrm{ml}$ of $8 \mathrm{M} \mathrm{NaOH}$ 184 with a syringe and shaking to prevent residual $\mathrm{HN}_{3}$ from escaping into the 185 laboratory during the subsequent isotopic analysis. These chemical treatments 186 were performed under wet conditions to prevent the evaporation of dissolved 187 organic nitrogen, which would affect the $\delta^{15} \mathrm{~N}$ values obtained after the re-drying 188 process after acid treatment and to recover all of the nitrogen in the skeletons.

189 The stable isotopic $\mathrm{N}_{2} \mathrm{O}$ composition was determined using our Continuous-Flow 190 Isotope Ratio Mass-Spectrometry (CF-IRMS) system (Tsunogai et al. 2008, 191 Konno et al. 2010; Hirota et al. 2010), which consists of an initial helium purge 192 and trap line, a gas chromatograph (Agilent 6890), and a Finnigan MAT 252

193 (Thermo Fisher Scientific, Waltham, MA, USA) with a modified Combustion III 194 interface. $\delta^{15} \mathrm{~N}$ values were determined relative to $\delta^{15} \mathrm{~N}$ of air. The standard 195 deviation of the coral sample measurements was less than $0.2 \%$ o $(\sigma, n=4)$ 196 (Yamazaki et al. 2013).

\section{Environmental data}

199 Daily precipitation data for $1958-2010$ on Ishigaki Island were available at the 200 website of the Japan Meteorological Agency (http://www.jma.go.jp). Monthly and 201 annual precipitation averages were calculated from the daily data. The 52-year $202 \delta^{15} \mathrm{~N}_{\text {coral }}$ record was compared with the land-use changes revealed by historic 203 aerial photographs and satellite images from Hasegawa (2011) and Ishihara et al. 204 (2014). Five land-use classes (forest, pasture, pineapple, paddy field and 205 sugarcane) were assigned. Aerial photographs from 1962, 1972, 1977/78, 1986, 2061989,1991 , and 1995 were classified by visual interpretation based on the texture 207 of the image (Hasegawa 2011), and satellite images from 2006 to 2008 were 208 classified using the decision tree method (e.g., Pal and Mather 2003) based on a 209 crop calendar as each category has specific seasonal changes in vegetation cover 210 (Ishihara et al. 2014).

\section{Results}


214 The groundwater (GW1, GW2, GW3, and GW4 in Fig.1a) had higher nitrate 215 concentrations $(>450 \mu \mathrm{M})$ than the river water. $\delta^{15} \mathrm{~N}_{\text {nitrate }}$ in the river water 216 increased from $+5.5-+6.4 \%$ in the upstream area to $+8.5 \%$ at the mouth. The 217 linear relationship $(\mathrm{R}=0.91, \mathrm{P}=0.01)$ between $\delta^{15} \mathrm{~N}_{\text {nitrate }}$ and $\delta^{18} \mathrm{O}_{\text {nitrate }}$ suggested 218 that the river water nitrate was a mixture of nitrate from spring water, field 219 drainage, and rainwater (Fig. 1b).

\section{Seasonal variation in $\delta^{\mathbf{1 5}} \mathbf{N}_{\text {coral }}$ for 1993-2007 (CORE1)}

222 The $\delta^{15} \mathrm{~N}_{\text {coral }}$ in CORE1 varied between $+0.1 \%$ and $+11 \%$ in monthly resolution 223 for $1993-2007$ (Fig. 3a). The average $\delta^{15} \mathrm{~N}_{\text {coral }}$ for these 14 years was $+6.4 \%{ }_{0} \pm 4 \%$ o $224(3 \sigma)$. The monthly $\delta^{15} \mathrm{~N}_{\text {coral }}$ in CORE1, calculated after linear interpolation to 225 replace the partially missing monthly values, was compared with the monthly total 226 precipitation (Fig. 3a). However, no relationship was found between the $\delta^{15} \mathrm{~N}_{\text {coral }}$ 227 and precipitation in a direct comparison. To define the seasonal characteristics of $228 \delta^{15} \mathrm{~N}_{\text {coral }}$ and precipitation, the 14-year averages of each monthly value of $\delta^{15} \mathrm{~N}_{\text {coral }}$ 229 and total precipitation were calculated (Fig. 3b, 3c). The rainy and typhoon 230 seasons for Ishigaki Island were in May-June and August-October, respectively 231 (Fig. 3c). The $\delta^{15} \mathrm{~N}_{\text {coral }}$ (Fig. 3b) gradually increased from May to October and 232 then gradually decreased over the following 5 months. The 5-month running mean 233 of $\delta^{15} \mathrm{~N}_{\text {coral }}$ had no correlation with that of monthly total precipitation; however, 234 with the exception of 1993-1995 and 2000-2001, the 5-month running mean of $235 \delta^{15} \mathrm{~N}_{\text {coral }}$ was positively correlated with that of precipitation less than $150 \mathrm{~mm} /$ day $236(\mathrm{R}=0.45, \mathrm{P}<<0.0001)$. Heavy rain (precipitation more than $150 \mathrm{~mm} /$ day), 237 indicated by white bars in Figure 3, corresponded with several positive peaks in $238 \delta^{15} \mathrm{~N}_{\text {coral }}$ but not all. From 1993 to $1995, \delta^{15} \mathrm{~N}_{\text {coral }}$ was continuously high $(>+6 \%$ ) 239 regardless of precipitation, and significantly different from 1996-2007 (analysis of 240 covariance; ANCOVA test (Schwarz 2011): $\mathrm{P}<<0.001$ ). During 2000-2001, the

241 5-month running mean of $\delta^{15} \mathrm{~N}_{\text {coral }}$ had a positive correlation with that of 242 precipitation of less than $150 \mathrm{~mm} /$ day $(\mathrm{R}=0.70, \mathrm{P}<0.0005)$, and the average of $243 \delta^{15} \mathrm{~N}_{\text {coral }}$ was $+5.3 \%$, which was $0.7 \%$ o lower than during 1996-2007 excluding 244 2000-2001. This difference was statistically significant (ANCOVA test: $245 \mathrm{P}<<0.001)$. 
247 The 52-year variation in $\boldsymbol{\delta}^{\mathbf{1 5}} \mathbf{N}_{\text {coral }}$ for 1958-2010 (CORE2)

248 The $\delta^{15} \mathrm{~N}_{\text {coral }}$ values in CORE2 varied between $+0.5 \%$ and $+14.8 \%$. The average

$249 \delta^{15} \mathrm{~N}_{\text {coral }}$ decreased from $+5.4 \%$ in $1958-1980$ to $+4.4 \%$ in $1981-2010$. The

250 annual averages of $\delta^{15} \mathrm{~N}_{\text {coral }}$ in CORE2 were compared with that in CORE1 during

251 1994-2006 (Fig.4a). During 1994-2006, the variations of $\delta^{15} \mathrm{~N}_{\text {coral }}$ were 2.7\%o,

252 (between $+4.9 \%$ and $+7.6 \%$ ) for CORE1, and 3.9\%o (between $+2.9 \%$ and

$253+6.8 \%$ ) for CORE2. The $\delta^{15} \mathrm{~N}_{\text {coral }}$ in CORE1 and CORE2 were not correlated. The

254 average values of $\delta^{15} \mathrm{~N}_{\text {coral }}$ were $+6.2 \%$ and $+5.0 \%$ for CORE1 and CORE2,

255 respectively.

256 The annual averages of $\delta^{15} \mathrm{~N}_{\text {coral }}$ in CORE2 were compared with the total 257 precipitation of the rainy season (May-June) (Fig. 4a). The cross-plot of the 258 average annual $\delta^{15} \mathrm{~N}_{\text {coral }}$ and the total precipitation of the rainy season showed a 259 weak linear relationship of $\mathrm{R}=0.39(\mathrm{P}=0.009)$ for $1958-2010$. The co-relationships 260 between $\delta^{15} \mathrm{~N}_{\text {coral }}$ and total precipitation of the rainy season were shifted to $\sim 1 \%$ 261 lower for $\delta^{15} \mathrm{~N}_{\text {coral }}$ and $51 \mathrm{~mm}$ higher for total precipitation from 1958-1980 to 262 1981-2010 (ANCOVA test: $\mathrm{P}=0.036(<0.05)$ ). The linear relationships between $263 \delta^{15} \mathrm{~N}_{\text {coral }}$ and the total precipitation of the rainy season showed $\mathrm{R}=0.80$ $264(\mathrm{p}<<0.0001)$ for $1958-1980$ and $\mathrm{R}=0.72(\mathrm{p}=0.0005)$ for 1981-2010 (Fig. 4b), 265 which was statically significant except for 1966, 1974, 1995, 1999, 2002, and 266 2006. The slopes in the former (1958-1980) and the latter (1981-2010) periods 267 were $144 \mathrm{~mm} \mathrm{\%}^{-1}$ and $166 \mathrm{~mm} \mathrm{\%}^{-1}$ respectively. In 1966, 1974, 1995, 1999, 2002, 268 and 2006, the $\delta^{15} \mathrm{~N}_{\text {coral }}$ and precipitation values of the rainy season were plotted 269 outside the standard deviation $(2 \sigma)$ from the linear regression lines in the former 270 and latter periods (Fig. 4b). The $\delta^{15} \mathrm{~N}_{\text {coral }}$ values for 1966 and 1974 were $-2.5 \%$ 271 and $-3.8 \%$, respectively, which were along the minima and smaller than expected 272 based on the linear trend of $\delta^{15} \mathrm{~N}_{\text {coral }}$ and precipitation in 1958-1980. By contrast, 273 the $\delta^{15} \mathrm{~N}_{\text {coral }}$ values for $1995,1999,2002$, and 2006 were $+2.5 \%$ o, $+3.9 \%$ o, $+3.2 \%$ o 274 and $+2.4 \%$, respectively, which were along the maxima and larger than expected 275 based on the linear trend of $\delta^{15} \mathrm{~N}_{\text {coral }}$ and precipitation in 1981-2010.

\section{Discussion}

278 Possible factors controlling $\boldsymbol{\delta}^{15} \mathbf{N}_{\text {coral }}$

279 This study examined the assumption that $\delta^{15} \mathrm{~N}_{\text {coral }}$ at the mouth of the Todoroki 280 River records nitrate loading from terrestrial origins, as suggested by Yamazaki et 
281 al. (2011b). The $\delta^{15} \mathrm{~N}_{\text {nitrate }}$ that flows from the Todoroki River into the coral reef is $282+8.5-+9 \%$ (Fig.3), indicating that it is affected by the land use in the catchment. $283 \delta^{15} \mathrm{~N}$ and $\delta^{18} \mathrm{O}$ composition of nitrate has been used for identification of 284 denitrification in river watershed. The dual fractionation factor of $\delta^{15} \mathrm{~N} / \delta^{18} \mathrm{O}$ is $285 \sim 1.3$ for denitrification (Fukuda et al. 2003). In Todoroki River water, the 286 fractionation factor of $\delta^{15} \mathrm{~N} / \delta^{18} \mathrm{O}$ was $\sim 3.0$ (Fig. 3), which suggests enrichment of

$287{ }^{15} \mathrm{~N}$ in river water is not affected by denitrification and but affected by external 288 nitrogen sources. We measured the $\delta^{15} \mathrm{~N}$ of total nitrogen in the agricultural water 289 from the dam, the mixture of chemical fertiliser and manure in the sugarcane 290 fields, and the excretion from cattle using same methods of $\delta^{15} \mathrm{~N}_{\text {coral }}$; the results 291 were $+2.5 \%$, $+9.1 \%$, and $+26.6 \%$, respectively. The mixture of each source 292 comprises the nitrate in the Todoroki River water. In this section, we discuss other 293 possible factors controlling $\delta^{15} \mathrm{~N}_{\text {coral }}$.

295 Terrestrial sediment. Inoue et al. (2014) reported the records of sediment 296 loading in CORE1 (as core L1) and CORE2 (as core L2) using iron (Fe) and 297 manganese $(\mathrm{Mn})$ as proxies. The effect of sediment loading was much smaller at 298 the CORE1 site than at the CORE2 site (Inoue et al. 2014). In CORE2, sediment 299 loading was small until the 1980s and increased remarkably from the 1990s 300 (Inoue et al. 2014). However, the variations in $\delta^{15} \mathrm{~N}_{\text {coral }}$ in CORE1 and CORE2 301 were not similar to those of the Fe and Mn proxies, suggesting that terrestrial 302 nitrate discharge is not simultaneous with sediment loading.

304 Light effect. Muscatine and Kaplan (1994) and Heikoop et al. (1998) reported 305 that deeper coral colonies had increased $\delta^{15} \mathrm{~N}$ in coral tissues due to increasing 306 coral heterotrophy. The light effect on $\delta^{15} \mathrm{~N}$ in coral tissues was $-1 \sim-2 \%$ o between 307 corals living at the surface and those at $30 \mathrm{~m}$ depth (Heikoop et al. 1998). $\delta^{15} \mathrm{~N}$ 308 differences were not observed in live corals at a depth of less than $10 \mathrm{~m}$ (Heikoop 309 et al. 1998). In this study, we examined corals living on a shallow reef (less than $3102 \mathrm{~m}$ depth). The effect of the position of the core top ( $\sim 50 \mathrm{~cm}$ depth differences 311 between the top and side) should be negligible. The seasonal cycle of solar 312 radiation is at a maximum in July-August and a minimum in December-January in 313 Ishigaki Island, as defined from 5-year solar irradiance data (1993-1997) for $\mathrm{N} 25^{\circ}$, $314 \mathrm{E} 125^{\circ} \quad(\mathrm{CAYAN}$ solar irradiance database; 
315 http://iridl.ldeo.columbia.edu/SOUCES/.CAYAN/.Si/). The seasonal variation of

$316 \delta^{15} \mathrm{~N}$ in CORE1 (Fig. 3b) did not correspond with the seasonal cycle of solar 317 radiation. In Reynaud et al. (2009), coral culture experiments also suggested that 318 light intensity does not affect $\delta^{15} \mathrm{~N}$ in coral tissue. In this study, the variations of $319 \delta^{15} \mathrm{~N}_{\text {coral }}$ at the mouth of the Todoroki River cannot be explained by light intensity.

321 Isotope fractionation between DIN and zooxanthellae. Heikoop et al. (1998) 322 suggested that $\delta^{15} \mathrm{~N}$ in coral tissues may vary due to isotope fractionation between 323 DIN in seawater and zooxanthellae. Isotope fractionation between DIN and 324 dinoflagellates was reported to be less than 3\%o (Needoba et al. 2003). We cannot 325 explain the 14\% range of variation in coral $\delta^{15} \mathrm{~N}$ by fractionation of DIN 326 assimilation of zooxanthellae alone. Yamazaki et al. (2011b) observed a 327 correspondence of $\delta^{15} \mathrm{~N}$ in nitrate and coral skeletons. This result also suggested 328 that the effect of isotope fractionation is negligible at the mouth of the Todoroki 329 River. For CORE1 and CORE2, possible factors controlling $\delta^{15} \mathrm{~N}_{\text {coral }}$ mainly 330 included $\delta^{15} \mathrm{~N}_{\text {nitrate }}$ in ambient seawater.

332 Coral $\boldsymbol{\delta}^{\mathbf{1 5}} \mathbf{N}$ of the nitrate outflow of the Todoroki River

333 The $\delta^{15} \mathrm{~N}_{\text {coral }}$ in CORE1 was continuously high (>+6\%) in 1993-1995. Blanco et 334 al. (2010) suggested that the controlling factor of $\mathrm{NO}_{3}{ }^{-} \mathrm{N}$ concentration at the 335 Todoroki River was mostly the percentage of sugarcane cover and bedrock type 336 (e.g., limestone) in the watershed. The percentage of sugarcane cover in Todoroki 337 watershed decreased from $68 \%$ in 1995 to $52 \%$ in 2006-2008 (Fig.5).

339 Since 1996, The results of CORE1 (Fig.3a) showed that the 5 month running 340 mean of monthly $\delta^{15} \mathrm{~N}_{\text {coral }}$ corresponded with that of precipitation, except during a 341 flood event (precipitation $>150 \mathrm{~mm} /$ day). The amount of river discharge 342 correlates with precipitation at present ( $\mathrm{R}=0.78$, ESM Fig. S3). At the mouth of the 343 Todoroki River, the $\delta^{15} \mathrm{~N}_{\text {coral }}$ could not respond to flood events because the nitrate 344 concentration of the rainwater runoff was $2-10 \%$ of the river/groundwater (Fig. 1, 345 Umezawa et al. 2002b). Blanco et al. (2010) reported that the nitrate concentration 346 at the mouth of Todoroki River tended to decrease during flood events in 2006 $347 \quad\left(\mathrm{NO}_{3}{ }^{-} \mathrm{N} ; 1 \mathrm{mg} / 1\right.$ of river discharge at $\left.\sim 8 \mathrm{~m}^{3} / \mathrm{s}\right)$ and to increase after the discharge 348 of the Todoroki River had decreased back to baseflow $\left(\mathrm{NO}_{3}{ }^{-} \mathrm{N} ; 3 \mathrm{mg} / 1\right.$ of river 
349 discharge at $0.5 \sim 1 \mathrm{~m}^{3} / \mathrm{s}$ ), which suggested that 1) most of precipitation run off as

350 floods with lower nitrate concentration, and 2) a portion of the rainwater soaked

351 into the soil of the river catchments, converted to groundwater accompanied by

352 nitrate and gathered in the Todoroki River after the flood event. In ESM Fgure S1,

353 the nitrate concentration and $\delta^{15} \mathrm{~N}_{\text {nitrate }}$ at the mouth of Todoroki River were

354 smaller $(118 \mu \mathrm{M}$ and $+8.1 \%)$ on 11 June 2011 , two week after the flood event

355 (228 mm/day), than in November 2010 (335 $\mu \mathrm{M}$ and $+9.1 \%$ ) without flood

356 events. This result suggests that floods dilute nitrate concentration and $\delta^{15} \mathrm{~N}_{\text {nitrate }}$

357 and that precipitation did not correspond with $\delta^{15} \mathrm{~N}_{\text {nitrate }}$ in flood events. The

358 seasonal variation of $\delta^{15} \mathrm{~N}_{\text {coral }}$ in Figure $3 \mathrm{~b}$ also suggests that rainwater was

359 reserved in the catchment area as groundwater in the rainy seasons and that nitrate

360 gradually seeped into the river with the stored water over the 4-5 months from

361 November to February. The $\delta^{15} \mathrm{~N}_{\text {coral }}$ in CORE1 recorded the loading of nitrate

362 from the land cover soil through the ground to river flow.

364 The seasonal variation of $\delta^{15} \mathrm{~N}_{\text {coral }}$ suggests that precipitation less than 150 $365 \mathrm{~mm} /$ day controlled the nitrate drainage into the Todoroki River through 366 groundwater. However, during 2000-2001, the $\delta^{15} \mathrm{~N}_{\text {coral }}$ was $0.7 \%$ lower than the 367 previously discussed 14-year average (Fig. 3), the cause of which is unknown.

368 The total monthly precipitation (except daily precipitation over $150 \mathrm{~mm}$ /day) in 369 2000-2001 was consistently higher than the average of total monthly precipitation 370 over the 14 years $(126 \mathrm{~mm} / \mathrm{month})$, which suggested the river water discharges 371 increased (ESM Fig.S3). The lower $\delta^{15} \mathrm{~N}_{\text {coral }}$ in 2000-2001 might suggest that 372 nitrate was diluted by the rainwater flow that was not converted to groundwater.

373 The $\delta^{15} \mathrm{~N}_{\text {coral }}$ of CORE1 suggested that the nitrate flowed into the coral reef with 374 precipitation and that the land use in the Todoroki River watershed could be the 375 cause of the quantity of discharged nitrate.

377 During 1994-2006, the average $\delta^{15} \mathrm{~N}_{\text {coral }}$ in CORE1 were 1.2\%o higher than that in 378 CORE2 (Fig.4a). The annual averages of CORE1 were varied around positive 379 peaks of CORE2. These results suggest that CORE1 was more influenced on the 380 nitrate discharge than CORE2 because the colony of CORE1 was located closer to 381 the shoreline than that of CORE2 (Fig.2a). In the Shiraho coral reef, the inner reef 382 distribution of $\delta^{15} \mathrm{~N}_{\text {nitrate }}$ has large gradient from inshore $(\sim+9 \%)$ to offshore 
383 ( $+3 \%$ ) (Fig. 2a, Yamazaki et al. 2011b). $\delta^{15} \mathrm{~N}_{\text {coral }}$ was sensitively changed by

$384 \delta^{15} \mathrm{~N}_{\text {nitrate }}$ changes with the locations of the coral colonies.

386 The nitrate sources have shifted with the land-use history in the catchment 387 area

388 The annual average of $\delta^{15} \mathrm{~N}_{\text {coral }}$ in CORE2 was correlated with the total 389 precipitation in the rainy season (May-June) (Fig. 4b). The 52-year record of the $390 \delta^{15} \mathrm{~N}_{\text {coral }}$ in CORE2 was divided into two periods: 1958-1980 and 1981-2010 (Fig. 391 4). Before 1980, the land use of the Todoroki River catchment was primarily 392 paddy fields, which were transformed into sugarcane fields after 1980 (Fig. 5). 393 The reclamation works began in the Todoroki River catchment after the Okinawa 394 reversion was agreed upon by Japan and the U.S. in 1972. The area of the paddy 395 fields decreased after the late 1970s, and sugarcane fields were cultivated using 396 chemical fertilisers beginning in the 1980s. The linear relationships between the 397 annual average of $\delta^{15} \mathrm{~N}_{\text {coral }}$ and the total precipitation in the rainy season were 398 similar between 1958-1980 and 1981-2010; however, the $\delta^{15} \mathrm{~N}_{\text {coral }}$ values 399 decreased approximately $+1 \%$ (Fig. 4b).

401 We analysed the nitrogen isotopes of the total nitrogen in the soil in sugarcane 402 fields and manure in the Todoroki River catchment using the same methods as in 403 the $\delta^{15} \mathrm{~N}_{\text {coral }}$ analysis. In the present day, the $\delta^{15} \mathrm{~N}$ of the mixture of chemical and 404 manure fertiliser was $+9 \%$ in the sugarcane fields. The $\delta^{15} \mathrm{~N}$ of the manure was $405+26 \%$, which was approximately three times greater than that of the fertiliser in 406 the sugarcane fields. The slopes of the linear relationships between $\delta^{15} \mathrm{~N}_{\text {coral }}$ and 407 precipitation were similar before and after 1980 (Fig. 4b). Given that the isotopic 408 composition of the nitrogen source term was approximately three times higher 409 prior to 1980 , it may be reasonable to assume that the nitrogen loading was only 410 approximately one-third as high to yield similar relationships between $\delta^{15} \mathrm{~N}_{\text {coral }}$ 411 and precipitation before and after 1980. Before the 1980s, the nitrate 412 concentration in the river water was one-third the nitrate concentration at present 413 (1981-2010), which assumes that 1) manure fertiliser was used in the paddy fields 414 before the $1980 \mathrm{~s}, 2$ ) the rate and magnitude of nitrate transport into the coral reef 415 due to the precipitation rate before and after 1980 were the same, and 3) current 416 values of nitrate in the sugarcane soil and manure were applied to the calculation. 
417 Hasegawa (2011) reported that sea grass bed coverage of Shiraho Coral Reef was 418 increased from $1.2 \%$ in 1972 to $7.2 \%$ in 2004 from the aerial photographs, which 419 also suggested terrestrial nutrient input was increased in these 30 years.

421 It was unclear why there were six outliners of $\delta^{15} \mathrm{~N}_{\text {coral }}$ in CORE2. The outliners of $422 \delta^{15} \mathrm{~N}_{\text {coral }}$ values in the pre-1980s, those for 1966 and 1974 were 2.5 and $3.8 \%$, 423 respectively, which was lower than expected even though the total precipitation of 424 the rainy season was higher than $700 \mathrm{~mm}$. The years 1966 and 1974 had the 425 second and third most precipitation before 1980, which might indicate that 426 abundant rainwater runoff flowed into the coral reefs through the river and diluted 427 the nitrate concentrations at the river mouth, as was recorded in 2000-2001 for $428 \delta^{15} \mathrm{~N}_{\text {coral }}$ in CORE1. By contrast, the four maxima $\delta^{15} \mathrm{~N}_{\text {coral }}$ values in 1995, 1999, 429 2002, and 2006 were 2.4-3.9\%o higher than expected. In typhoon events, it is 430 possible that the nitrogenous nutrients in the fertiliser were directly loaded with 431 sediments into the coral reefs through the Todoroki River. In Ishigaki Island, the 432 sediment loading from the paddy fields into the river is smaller than usual in flood 433 event because the paddy fields work as sediment reservoir (Ikeda et al. 2009). 434 However, instead of the paddy fields, the sugarcane fields prospered in the 435 Todoroki River catchments since 1980, especially after the late 1980s (Fig. 5). 436 The fertiliser inflow with sedimentation might have influenced the four maxima 437 of the $\delta^{15} \mathrm{~N}_{\text {coral }}$. We compared the $\delta^{15} \mathrm{~N}_{\text {coral }}$ values for 1995, 1999, 2002, and 2006 438 with the total precipitation in the typhoon season (August to October) (triangle 439 points in Fig. 4b). The modified cross-plots in 1995, 1999, and 2006 were plotted 440 within the standard deviation $(2 \sigma)$ from the linear regression lines. However, the

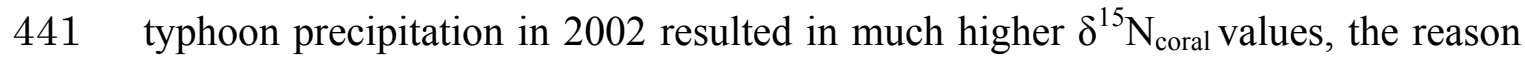
442 for which remains unknown and needs future works.

444 The $\delta^{15} \mathrm{~N}_{\text {coral }}$ at the mouth of the Todoroki River recorded the nitrate discharge 445 caused by the precipitation mainly in the rainy season, and the nitrate sources 446 changed with the changing land use in the Todoroki River catchment. Although 447 future work is needed to give the spatial and temporal inconsistencies of the proxy 448 relationship, the $\delta^{15} \mathrm{~N}_{\text {coral }}$ can be used as a proxy for the source and discharge 449 pattern of terrestrial nitrate in coral reefs. 
Coral and water sampling for this study were supported by CREES members of

Hokkaido University, Toshiaki Tanaka, Teppei Sagawa, Satoshi Maekawa, and the WWF Coral Reef Conservation and Research Centre. Coral core cutting was supported by Masataka Ikeda. The research was funded by a Grant-in-Aid for Scientific Research on Innovative Areas 'Coral reef science for symbiosis and coexistence of human and ecosystem under combined stresses' (\#20121004) from the Ministry of Education, Culture, Sports, Science and Technology (MEXT) of Japan. A.

\section{References}

Adachi H, Abe O (2003) Air drill for submerged massive coral drilling. Mar Technol Soc Bull 37: 31-36

Bellwood DR, Hughes TP, Folke C, Nystrom M (2004) Confronting the coral reef crisis. Nature, 429: 827-833

Blanco AC, Nadaoka K, Yamamoto T (2008) Planktonic and benthic microalgal community composition as indicators of terrestrial influence on a fringing reef in Ishigaki Island, Southwest Japan. Mar Environ Res 66: 520-535

Blanco AC, Nadaoka K, Yamamoto T, Kinjo K (2010) Dynamic evolution of nutrient discharge under stormflow and baseflow conditions in a coastal agricultural watershed in Ishigaki Island, Okinawa, Japan. Hydrol Process 24: 2601-2616

De'ath G, Fabricius KE, Sweatman H, Puotinen M (2012) The 27-year decline of coral cover on the Great Barrier Reef and its causes. Proc Natl Acad Sci USA 109: 17995-17999

Druffel ERM (1997a) Geochemistry of corals: proxies of past ocean chemistry, ocean circulation, and climate. Proc Natl Acad Sci USA 94: 8354-8361

Fabricius K (2005) Effects of terrestrial runoff on the ecology of corals and coral reefs: review and synthesis. Mar Pollut Bull 50: 125-146

Fukada T, Hiscock KM, Dennis PF, Grischek T (2003) A dual isotope approach to identify denitrification in groundwater at a river-bank infiltration site. Water Res 37: 3070-3078

Gagan MK, Ayliffe LK, Beck JW, Cole JE, Druffel ERM, Dunbar RB, Schrag DP (2000) New views of tropical paleoclimates from corals. Quat Sci Rev 19: 45-64

Grottoli A, Eakin C (2007) A review of modern coral $\delta^{18} \mathrm{O}$ and $\Delta 14 \mathrm{C}$ proxy records. Earth Sci Rev 81: 67-91

Hasegawa H (2011) The decline of coral reef conditions caused by the extensive land modification: A case study of the Shiraho area on Ishigaki Island, Okinawa, Japan. Journal of the Remote Sensing Society of Japan 31: 73-86

Heikoop JM, Dunn JJ, Risk MJ, Sandeman IM, Schwarcz HP, Waltho N (1998) Relationship between light and the $\delta^{15} \mathrm{~N}$ of coral tissue: Examples from Jamaica and Zanzibar. Limnol Oceanogr 43: 909-920

Heikoop JM, Dunn JJ, Risk MJ, Tomascik T, Schwarcz HP, Sandeman IM, Sammarco $\mathrm{PW}(2000) \delta^{15} \mathrm{~N}$ and $\delta^{13} \mathrm{C}$ of coral tissue show significant inter-reef variation. Coral Reefs 19: 189-193

Hirota A, Tsunogai U, Komatsu DD, Nakagawa F (2010) Simultaneous determination of $\delta^{15} \mathrm{~N}$ and $\delta^{18} \mathrm{O}$ of $\mathrm{N}_{2} \mathrm{O}$ and $\delta^{13} \mathrm{C}$ of $\mathrm{CH}_{4}$ in nanomolar quantities from a single water sample. Rapid Commun Mass Spectrom, 24: 1085-1092

Hoegh-Guldberg O, Mumby PJ, Hooten AJ, Steneck RS, Greenfield P, Gomez E, Harvell CD, Sale PF, Edwards AJ, Caldeira K, Knowlton N, Eakin CM, Iglesias-Prieto R, Muthiga N. Bradbury RH, Dubi A, Hatziolos ME (2007) Coral reefs under rapid climate change and ocean acidification. Science 318: 1737-1742

Ikeda S, Osawa K, Akamatsu Y (2009) Sediment and nutrients transport in watershed and their impact on coastal environment. Proc Jpn Acad Ser B 85: 374-390

Inoue M, Ishikawa D, Miyaji T, Yamazaki A, Suzuki A, Yamano H, Kawahata H, Watanabe T (2014) Evaluation of Mn and Fe in coral skeletons (Porites spp.) as proxies for sediment loading and reconstruction of $50 \mathrm{yrs}$ of land use on Ishigaki Island, Japan. Coral Reefs 33: 363-373.

Ishihara M, Hasegawa H, Hayashi S, Yamano H (2014) Land cover classification using multi-temporal satellite images in a subtropical area. In: Nakano S, Yahara 
T, Nakashizuka T (eds) The biodiversity observation network in the Asia-Pacific region: Integrative observations and assessments of Asian biodiversity. Springer, pp231-237

Knapp AN, Sigman DM, Lipschultz F (2005) N isotopic composition of dissolved organic nitrogen and nitrate at the Bermuda Atlantic Time-series Study site. Global Biogeochem Cycles 19: GB1018

Konno U, Tsunogai U, Komatsu DD, Daita S, Nakagawa F, Tsuda A, Matsui T, Eum YJ, Suzuki K (2010) Determination of total $\mathrm{N}_{2}$ fixation rates in the ocean taking into account both the particulate and filtrate fractions. Biogeosciences 7: 2369-2377

Marion G, Dunbar R, Mucciarone D, Kremer J, Lansing J, Arthawiguna A (2005) Coral skeletal $\delta^{15} \mathrm{~N}$ reveals isotopic traces of an agricultural revolution. Mar Pollut Bull 50: 931-944

Miyajima T, Suzumura M, Umezawa Y, Koike I (2001) Microbiological nitrogen transformation in carbonate sediments of a coral-reef lagoon and associated seagrass beds. Mar Ecol Prog Ser 217: 273-286

Muscatine L, Kaplan IR (1994) Resource partitioning by reef corals as determined from stable isotope composition. II. ${ }^{15} \mathrm{~N}$ of symbiotic dinoflagellates and animal tissue versus depth. Pac Sci 48: 304-312

Needoba JA, Waser NA, Harrison PJ, Calvert SE (2003) Nitrogen isotope fractionation in 12 species of marine phytoplankton during growth on nitrate. Mar Ecol Prog Ser 255: 81-91

Pal M, Mather PM (2003) An assessment of the effectiveness of decision tree methods for land cover classification. Remote Sens Environ 86: 554-565

Reynaud S, Martinez P, Houlbrèque F, Billy I, Allemand D, Ferrier-Pagès C (2009) Effect of light and feeding on the nitrogen isotopic composition of a zooxanthellate coral: role of nitrogen recycling. Mar Ecol Prog Ser 392: 103-110

Tsunogai U, Kido T, Hirota A, Ohkubo SB, Komatsu DD, Nakagawa F (2008) Sensitive determinations of stable nitrogen isotopic composition of organic nitrogen through chemical conversion into $\mathrm{N}_{2} \mathrm{O}$. Rapid Commun Mass Spec 22: 345-354

Schwarz CJ (2011) Sampling, regression, experimental design and analysis for environmental scientists, biologists and resource managers. Department of Statistics and Actuarial Science, Simon Fraser University, p57

Uchida A, Nishizawa M, Shirai K, Iijima H, Kayanne H, Takahata N, Sano Y (2008) High sensitivity measurements of nitrogen isotopic ratios in coral skeletons from Palau, western Pacific: Temporal resolution and seasonal variation of nitrogen sources. Geochem J 42: 255-262

Umezawa Y, Miyajima T, Koike I (2008) Stable nitrogen isotope composition in sedimentary organic matter as a potential proxy of nitrogen sources for primary producers at a fringing coral reef. J Oceanogr 64: 899-909

Umezawa Y, Miyajima T, Kayanne H, Koike I (2002b) Significance of groundwater nitrogen discharge into coral reefs at Ishigaki Island, southwest of Japan. Coral Reefs 21: 346-356

Umezawa Y, Miyajima T, Yamamuro M, Kayanne H, Koike I (2002a) Fine scale mapping of land-derived nitrogen in coral reefs, by $\delta^{15} \mathrm{~N}$ values in macroalgae. Limnol Oceanogr 47: 1405-1416

Yamamuro M, Kayanne H, Yamano H (2003) $\delta^{15} \mathrm{~N}$ of seagrass leaves for monitoring anthropogenic nutrient increases in coral reef ecosystems. Mar Pollut Bull 46: $452-458$

Yamazaki A, Watanabe T, Tsunogai U (2011b) Nitrogen isotopes of organic nitrogen in reef coral skeletons as a proxy of tropical nutrient dynamics. Geophys Res Lett 38: L19605

Yamazaki A, Watanabe T, Takahata N, Sano Y, Tsunogai U (2013) Nitrogen isotopes in intra-crystal coralline aragonites. Chem Geol 351: 276-280

Yamazaki A, Watanabe T, Ogawa NO, Ohkouchi N, Shirai K, Toratani M, Uematsu M (2011a) Seasonal variations in the nitrogen isotope composition of Okinotori coral in the tropical western Pacific: A new proxy for marine nitrate dynamics. J 
$569 \quad$ Figure Legends

Fig. 1. Land-use and nitrate isotope compositions of the Todoroki River catchment. (a) Land use of the Todoroki river catchment in October 2010. The white (॰) and black (•) circles show the nitrate concentrations with the $\delta^{15} \mathrm{~N}_{\text {nitrate }}$ in river water $(\mathrm{RW})$ and ground water $(\mathrm{GW})$, respectively. The RW samples were taken in March and August 2009. The GW, and rainwater were also sampled in August 2009. (b) Cross-plot of the $\delta^{15} \mathrm{~N}_{\text {nitrate }}$ and $\delta^{18} \mathrm{O}_{\text {nitrate }}$ in $\mathrm{RW}, \mathrm{GW}$ and rainwater from August 2009. Isotope composition of RW1 was affected by rainwater. Except for RW1, the correlation coefficient was $\mathrm{R}=0.91(\mathrm{p}=0.01)$.

Fig. 2. (a) The relationships between the distance of the sampling sites from the shoreline and $\delta^{15} \mathrm{~N}$ in Porites coral skeletons, seawater nitrate, and macro algae (DIN consumers), compiled from Yamazaki et al. (2011a) and Umezawa et al. (2002). $\delta^{15 \mathrm{~N}}$ values decreased from $+9 \%$ inshore to $+2 \sim+3 \%$ offshore. (b)The relationship between the nitrate concentration and the $\delta^{15} \mathrm{~N}_{\text {nitrate }}$ in the seawater of the Shiraho coral reef. The $\delta 15 \mathrm{~N}_{\text {nitrate }}$ from +2 to $+9 \%$ positively correlates with the natural logarithm of the nitrate concentration $(\mathrm{R}=0.85, \mathrm{p}<0.004)$.

Fig. 3. (a) The time series of the $\delta^{15} \mathrm{~N}_{\text {coral }}$ (green line graph with dots) in CORE1 from 1993 to 2007 compared with the monthly total precipitation for Ishigaki Island. The blue bar graph shows the monthly total precipitation without the heavy precipitation (>150 mm/day, white bar). The black lines indicate five-month running averages. The 5 -month running mean of $\delta^{15} \mathrm{~N}_{\text {coral }}$ was positively correlated with that of precipitation of less than $150 \mathrm{~mm} /$ day $(\mathrm{R}=0.48, \mathrm{P}<0.0001)$, with the exception of $1993-1995$ and 2000-2001. From 1993 to $1995, \delta^{15} \mathrm{~N}_{\text {coral }}$ was continuously high $(>+6 \%$ ), regardless of precipitation. During 2000-2001, the 5-month running mean of $\delta 15 \mathrm{~N}_{\text {coral }}$ was positively correlated with that of precipitation of less than $150 \mathrm{~mm} / \mathrm{day}(\mathrm{R}=0.62, \mathrm{P}<0.0005)$, and the average of $\delta^{15} \mathrm{~N}_{\text {coral }}$ was $+5.3 \%$, which was $0.7 \%$ lower than during 1996-2007 excluding 2000-2001 (b) The bar graph of 14-year averages of 12 monthly $\delta^{15} \mathrm{~N}_{\text {coral }}$ in CORE1. (c) The bar graph of 14-year averages of 12 monthly total precipitations.

Fig. 4. (a) The time series of the $\delta^{15} \mathrm{~N}_{\text {coral }}$ in CORE2 from 1958 to 2010 compared with the bar graphs of the total precipitation in the rainy season (May-June). The dotted line shows the analysed $\delta^{15} \mathrm{~N}_{\text {coral }}$ in sub-annual to annual intervals. The green bold line shows the annual averages with the plots of the symbols corresponding with (b). The red solid line shows annual average of $\delta^{15} \mathrm{~N}_{\text {coral }}$ from CORE1. (b) The cross plot between the annual average of $\delta^{15} \mathrm{~N}_{\text {coral }}$ and the total precipitation in the rainy season (May-June); black circles (•) indicate 1958-1981, and white circles (०) indicate 1981-2010. The outliners in 1966 and 1974 are shown as grey circles $(\bullet)$. The outliners of $\delta^{15} \mathrm{~N}_{\text {coral }}$ in 1995, 1999, 2002, and 2006 are showed as white circles (o) compared with precipitation in rainy season (May-June), and white circles connected with dashed line to triangles are compared with precipitation in typhoon season (September-October). The correlation coefficients $(\mathrm{R})$ are $0.80(\mathrm{P}<<0.0001)$ and $0.72(\mathrm{P}=0.0005)$ in the former (1958-1980) and latter (1981-2010) periods, respectively. The ranges of standard deviation $(2 \sigma)$ are indicated as green and yellow shades for the former and latter periods. The slopes are $166 \mathrm{~mm} \% \mathrm{o}^{-1}$ and $144 \mathrm{~mm} \%{ }^{-1}$, respectively. The cross-plots of average $\delta^{15} \mathrm{~N}_{\text {coral }}$ and average total precipitation in May-June are described as a black square $(\square:+5.4 \%, 430 \mathrm{~mm})$ and a white square $(\square:+5.4 \%, 430 \mathrm{~mm})$ for the former and latter periods.

Fig. 5. The land-use history in the Todoroki River catchment and pie charts of the area ratios. 
622 Fig. S1. The seasonal variation of nitrogen isotopes and nitrate concentrations at the 623 mouth of the Todoroki River. The nitrogen isotopes in the samples of nitrate 624 concentrations less than $0.5 \mu \mathrm{M}$ are unknown due to the detection limits. The allows 625 indicate the direction of prevailing currents based on Tamura et al. (2007)

627 Fig.S2. X-radiographs and analytical lines for CORE1 and CORE2.

629 Fig.S3. Relationship between monthly river discharge and monthly precipitation in 630 the Todoroki River catchment. The data was collected from November 2006 to 631 November 2007 by the government of Okinawa prefecture.

633 References. Tamura H, Nadaoka K, Paringit EC (2007) Hydrodynamic characteristics 634 of a fringing coral reef on the east coast of Ishigaki Island, southwest Japan. Coral 635 Reefs 26: $17-34$ 

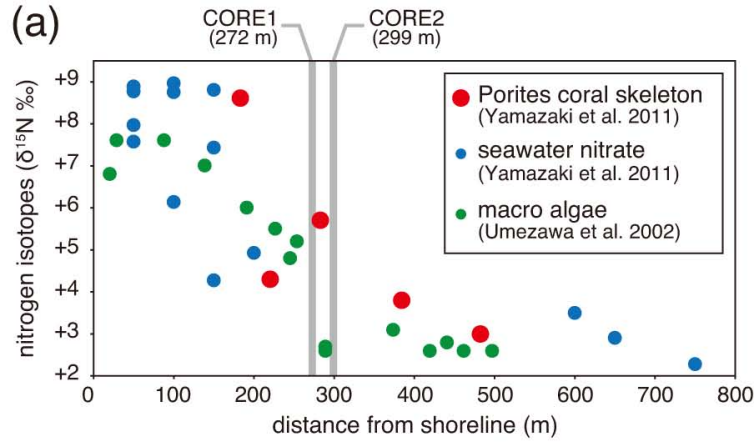

(b)

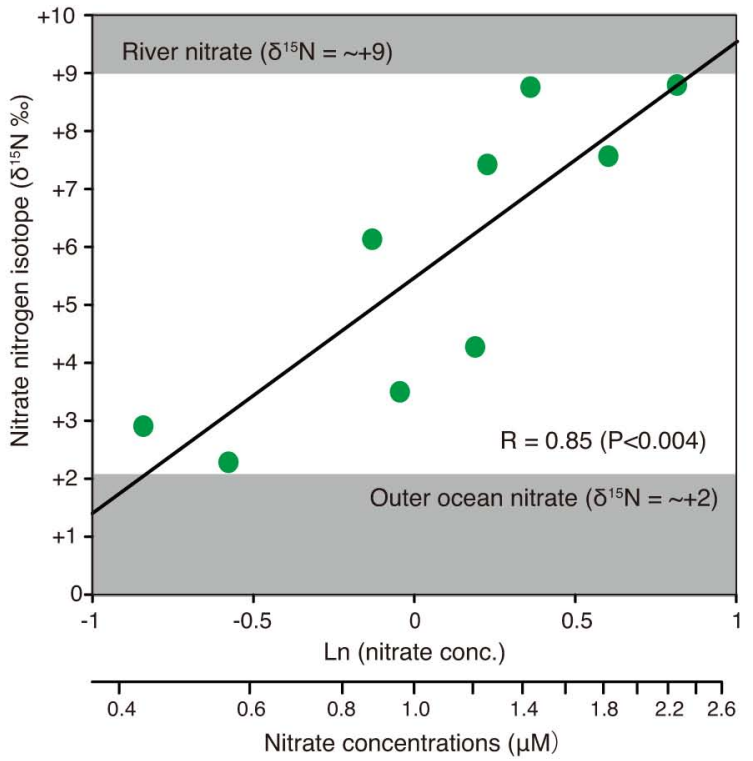




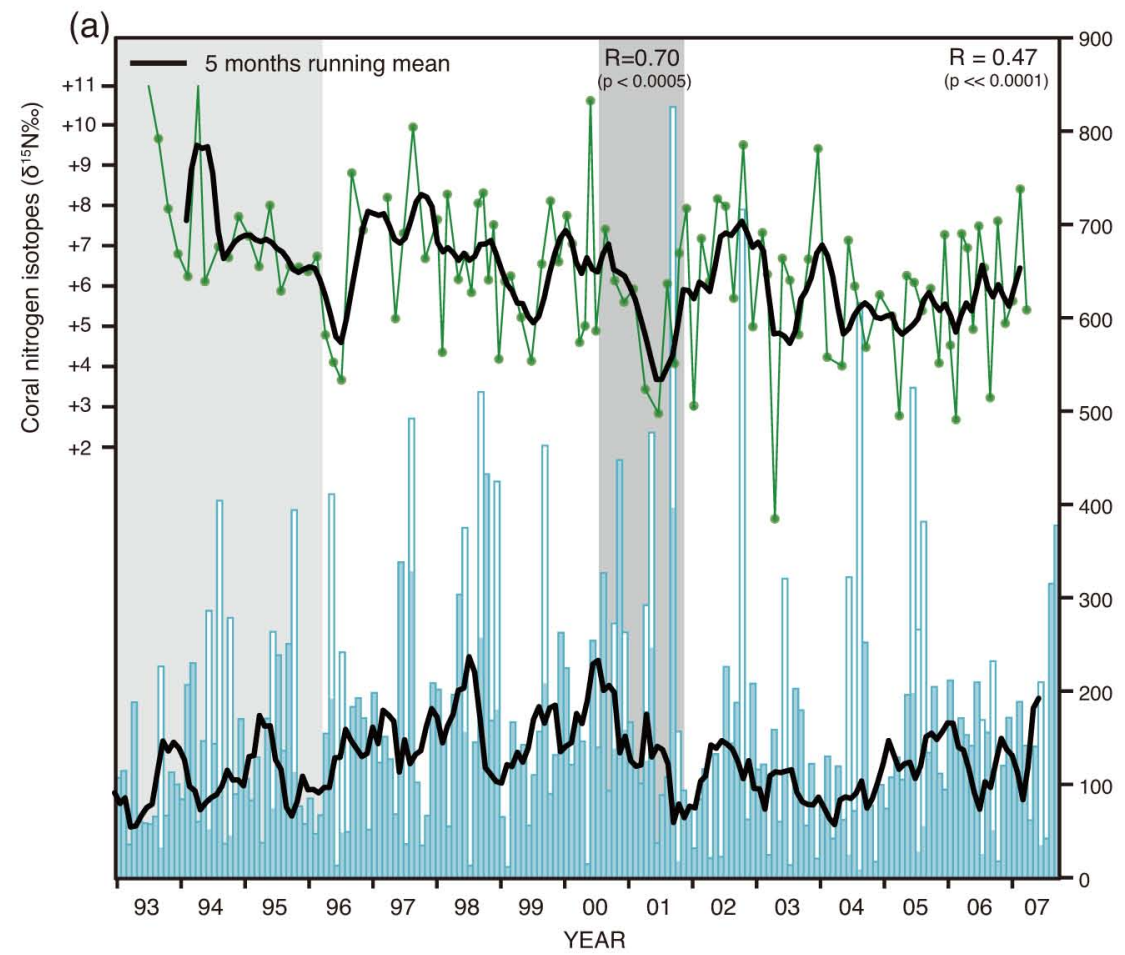

(b)

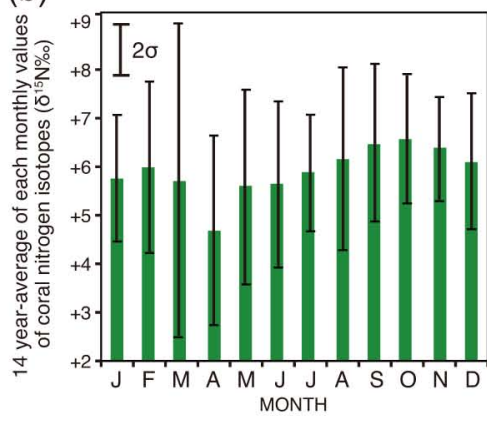

(c)

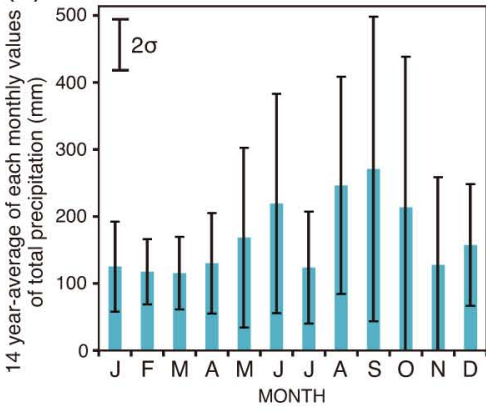


(a)

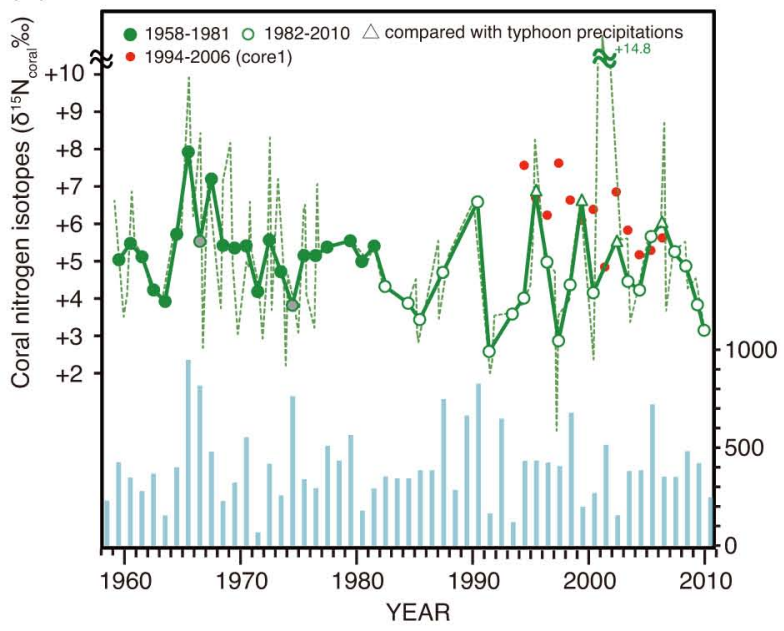

(b)

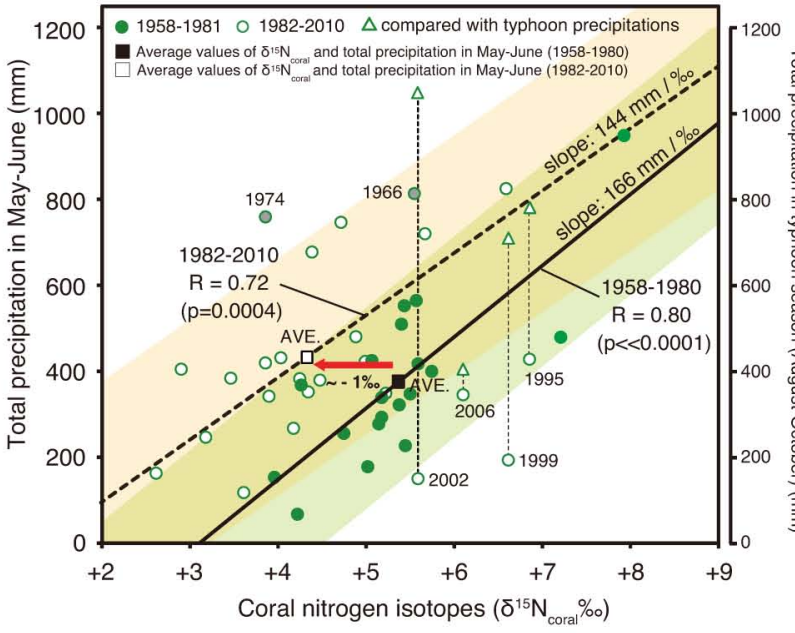




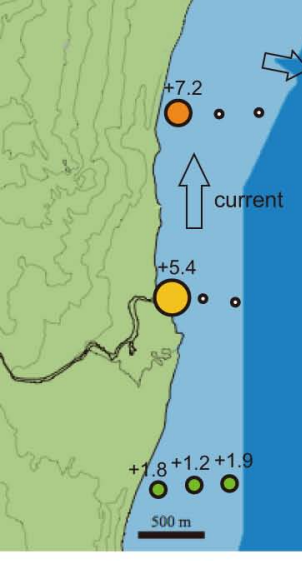

Mar 2011

Precipitation rate: $8.7 \mathrm{~mm} /$ day

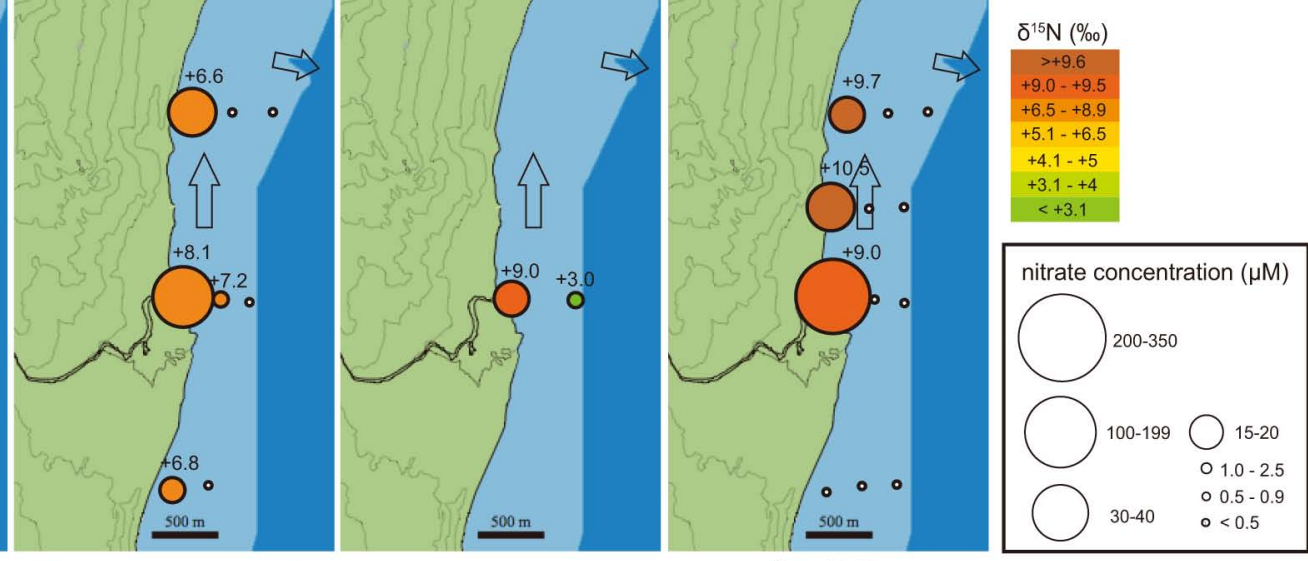

Rainy season (Jun 2011)

Precipitation rate: $18.5 \mathrm{~mm} /$ day

Aug 2009

Precipitation rate: $6.3 \mathrm{~mm} /$ day
Nov 2010

Precipitation rate: $12.8 \mathrm{~mm} /$ day Flood events: $288 \mathrm{~mm} /$ day $(5 / 28)$ 
CORE1

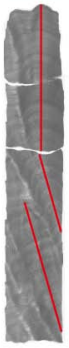

㲚

\section{CORE2}
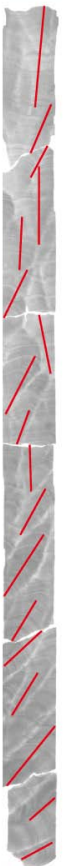
